\title{
RESPON PEMBERIAN PUPUK NPK TERHADAP PERTUMBUHAN BIBIT KOPI ROBUSTA (Coffee robusta)
}

\author{
Syahruni Thamrin, Junaedi, Irmayana \\ Prodi Budidaya Tanaman Perkebunan, Jurusan Budidaya Tanaman Perkebunan \\ Politeknik Pertanian Negeri Pangkajene Kepulauan \\ Jl. Poros Makassar Pare-Pare KM 83 Mandalle, Kab. Pangkep \\ Korespondensi : syahrunithamrin@gmail.com
}

\begin{abstract}
ABSTRAK
Penelitian bertujuan mengetahui pengaruh berbagai dosis pupuk NPK terhadap pertumbuhan bibit tanaman kopi robusta. Penelitian dilakukan di screen house Jurusan Budidaya Tanaman Perkebunan Politeknik Pertanian Negeri Pangkep. Penelitian menggunakan analisis statistik sederhana dengan pola Rancangan Acak Lengkap (RAL) yaitu menghitung nilai tengah (ratarata) dari masing-masing perlakuan percobaan yang terdiri dari 3 taraf perlakuan, yaitu: tanpa pemberian pupuk NPK, pemberian pupuk NPK dengan dosis 14 gram, pemberian pupuk NPK dengan dosis 18 gram, dan pemberian pupuk NPK dengan dosis 22 gram. Hasil menunjukkan bahwa pemberian pupuk NPK berpengaruh tidak nyata terhadap tinggi tanaman, jumlah daun dan diameter batang bibit tanaman kopi. Perlakuan terbaik untuk tinggi tanaman adalah pemberian pupuk NPK dengan dosis 18 gram, untuk jumlah daun adalah pemberian pupuk NPK dengan dosis 22 gram, dan untuk diameter batang semua perlakuan sama kecuali dosis 14 gram yang paling kecil.
\end{abstract}

Kata kunci: dosis pupuk, pupuk NPK, kopi robusta.

\begin{abstract}
This study aims to determine the effect of various NPK fertilizer doses on the growth of Robusta coffee seedlings. The study was conducted in the screen house of the Department of Plantation Plant Cultivation at the Pangkep State Polytechnic of Agricultural. The study used a simple statistical analysis with a Completely Randomized Design (CRD) pattern, which was to calculate the mean (average) of each experimental treatment consisting og 3 treatment levels, namely: without applying NPK fertilizer, NPK fertilizer at a dose of 14 grams, giving NPK fertilizer at a dose of 18 grams, and giving NPK fertilizer at a dose of 22 grams. The results showed that NPK fertilizer application had no significant effect on plant height, number of leaves and stem diameter of coffee plant seedlings. The best treatment for plant height was NPK fertilizer at a dose of 18 grams. For the number of leaves was NPK fertilizer at a dose of 22 grams. And for stem diameter all treatments were the same except for the smallest 14 gram dose.
\end{abstract}

Keywords: fertilizer dosage, NPK fertilizer, Robusta coffee. 


\section{PENDAHULUAN}

Tanaman kopi robusta memiliki adaptasi yang lebih baik dibandingkan dengan kopi jenis Arabika. Areal perkebunan kopi jenis robusta di Indonesi relatif luas, karena kopi jenis robusta dapat tumbuh di ketinggian yang lebih rendah dibandingkan dengan lokasi perkebunan kopi arabika (Panggabean, 2010). Kopi ini ternyata tahan penyakit karat daun, dan memerlukan syarat tumbuh dan pemeliharaan yang ringan, sedang produksinya jauh lebih tinggi. Oleh karena itu kopi ini cepat berkembang, dan mendesak kopi-kopi lainnya. Saat ini lebih dari 90\% dari areal pertanaman kopi Indonesia terdiri atas kopi Robusta (Prastowo et al., 2010).

Kini lebih dari 120 spesies kopi telah diidentifikasi namun hanya satu spesies yaitu Coffea canephora atau kopi robusta yang dibudidayakan mendekati kuantitas kopi arabika di seluruh dunia (Hoffman, 2014). Mekuria et al., (2004) menyatakan bahwa 66\% produksi kopi dunia merupakan jenis kopi arabika dan sisanya berasal dari kopi robusta.

Jika dilihat dari jenis kopi yang diusahakan dari tahun 2001 sampai dengan tahun 2016, mayoritas pekebun kopi di Indonesia menanam kopi jenis robusta. Meskipun demikian luas areal kopi robusta cenderung menurun sementara luas areal kopi arabika cenderung meningkat. Pada tahun 2001, luas areal kopi robusta di Indonesia mencapai 1.232.551 ha dan tahun 2016 menjadi 912.135 ha atau terjadi penurunan sebesar 26,00\% dibandingkan luas areal pada tahun 2001. Sementara luas areal kopi arabika pada tahun 2001 hanya mencapai 82.807 ha, kemudian luasan ini meningkat sebesar 287,84\% pada tahun 2016 menjadi 321.158 ha. (Kementerian Pertanian, 2016).

Kopi robusta lebih mudah untuk ditanam. Kopi robusta dapat ditanam pada ketinggian rendah sekitar 200-800 meter dari permukaan laut dan tidak mudah diserang hama. Kadar kafein yang tinggi pada kopi robusta bermanfaat sebagai pertahanan terhadap hama karena kadar kafein yang tinggi tersebut menjadi racun bagi hama. Kopi robusta juga menghasilkan lebih banyak biji kopi per hektar, dengan biaya produksi yang juga lebih kecil.

Salah satu penyebab rendahnya produktivitas kopi robusta di Indonesia adalah belum digunakannya bahan tanam unggul yang sesuai dengan agroekosistem tempat tumbuh kopi robusta. Umumnya petani masih menggunakan bahan tanam dari biji yang berasal dari pohon yang memiliki buah lebat atau bahkan dari benih sapuan (Prastowo et al., 2010). Selain itu faktor budidaya tanaman kopi sangat penting diperhatikan untuk meningkatkan produksinya, khususnya dalam hal media tanam bibit dan pemupukan bibit.

Media tanam sebagai tempat tumbuh tanaman kopi berperan penting untuk pertumbuhan dan mendapatkan bibit yang baik. Sutedjo (2008) menyatakan bahwa media yang 
baik mempunyai agregat yang mantap, tekstur lempung berliat, kapasitas menahan air yang cukup baik dan total pori yang optimal. Selain itu media harus memiliki kesuburan tanah yang baik, mengandung bahan organik yang tinggi serta tidak terdapat zat yang beracun. Tanah top soil yang merupakan salah satu media tanam dalam pembibitan kopi Robusta sangat penting diperhatikan kondisi kesuburannya. Sutedjo (2008) menyatakan bahwa pemakaian tanah secara rutin dan minimnya usaha perawatan menyebabkan semakin sedikit tanah tersebut ditemukan terutama lapisan top soil, sehingga timbul ide untuk mempersiapkan media yang baik dicampur tanah dan pupuk kandang.

Disamping media tanam, pemupukan pada pembibitan kopi Robusta juga sangat penting diperhatikan khususnya pupuk NPK. AAK (1991) menyatakan bahwa kombinasi pemberian $\mathrm{N}, \mathrm{P}_{2} \mathrm{O}_{5}, \mathrm{~K}_{2} \mathrm{O}$ akan memperkuat jaringan sel tanaman, sehingga memungkinkan tanaman cepat pulih kembali dari efek negatif musim kemarau. Oleh karena itu pemberian pupuk yang cukup akan menjamin mutu produksi yang tinggi. Pupuk NPK merupakan pupuk majemuk yang mengandung unsur hara utama lebih dari dua jenis. Dengan kandungan unsur hara Nitrogen $15 \%$ dalam bentuk $\mathrm{NH}_{3}$, fosfor $15 \%$ dalam bentuk $\mathrm{P}_{2} \mathrm{O}_{5}$, dan kalium $15 \%$ dalam bentuk $\mathrm{K}_{2} \mathrm{O}$. Sifat Nitrogen (pembawa nitrogen ) terutama dalam bentuk amoniak akan menambah keasaman tanah yang dapat menunjang pertumbuhan tanaman (Hardjowigeno, 2007).

Menurut Najiyarti dan Danarti (1997) dosis pemupukan bibit kopi yang dapat digunakan menurut umurnya adalah sebagai berikut: Umur 3 bulan membutuhkan $10 \mathrm{~g}$ urea $/ \mathrm{m}^{2}, 5 \mathrm{~g}$ $\mathrm{TSP} / \mathrm{m}^{2}$ dan $5 \mathrm{~g} \mathrm{KCl} / \mathrm{m}^{2}$; Umur 5 bulan membutuhkan $20 \mathrm{~g}$ urea $/ \mathrm{m}^{2}, 10 \mathrm{~g} \mathrm{TSP} / \mathrm{m}^{2}$ dan $10 \mathrm{~g}$ $\mathrm{KCl} / \mathrm{m}^{2}$; Umur 7 bulan membutuhkan $30 \mathrm{~g}$ urea $/ \mathrm{m}^{2}, 15 \mathrm{~g} \mathrm{TSP} / \mathrm{m}^{2}$ dan $15 \mathrm{~g} \mathrm{KCl} / \mathrm{m}^{2}$; Umur 9 bulan membutuhkan $40 \mathrm{~g}$ urea/ $/ \mathrm{m}^{2}, 20 \mathrm{~g} \mathrm{TSP} / \mathrm{m}^{2}$ dan $20 \mathrm{KCl} / \mathrm{m}^{2}$; Umur 12 bulan membutuhkan $50 \mathrm{~g}$ urea $/ \mathrm{m}^{2}, 25 \mathrm{~g} \mathrm{TSP} / \mathrm{m}^{2}$ dan $25 \mathrm{KCl} / \mathrm{m}^{2}$.

Pemupukan NPK pada kopi perlu dilakukan saat mulai dari pembibitan untuk menjamin dihasilkannya bibit yang baik dan sehat. Dengan dihasilkannya bibit yang baik dan sehat maka diharapkan dapat dihasilkan pertumbuhan dan produksi tanaman dewasa yang baik. Dalam pemupukan tanaman banyak hal yang perlu diperhatikan. Salah satu diantaranya adalah penetapan dosis pemupukan. Ketidaktepatan dan ketidakseimbangan dosis pemupukan atau penambahan unsur dapat menghambat ketersediaan unsur lain yang pada akhirnya dapat berakibat jelek bagi tanaman.

Berdasarkan hal tersebut maka perlu dilakukan penelitian untuk mengetahui pengaruh pemberian pupuk NPK terhadap pertumbuhan bibit tanaman kopi robusta. 


\section{BAHAN DAN METODE}

Penelitian dilaksanakan di Kebun Percobaan Jurusan Budidaya Tanaman Perkebunan Politeknik Negeri Pangkep, mulai bulan Oktober hingga bulan Desember tahun 2018.

Bahan yang digunakan dalam penelitian ini adalah pupuk NPK Phonska Dengan kandungan unsur hara Nitrogen $15 \%$ dalam bentuk $\mathrm{NH}_{3}$, fosfor $15 \%$ dalam bentuk $\mathrm{P}_{2} \mathrm{O}_{5}$, dan kalium $15 \%$ dalam bentuk $\mathrm{K}_{2} \mathrm{O} .15 \%$, air, bibit kopi robusta (umur 5 bulan), dan label. Alat yang digunakan yaitu: timbangan analitik, jangka sorong, mistar, kamera, alat tulis menulis.

Penelitian ini menggunakan Rancangan Acak Lengkap (RAL) dengan empat taraf perlakuan sebagai berikut: tanpa pemberian pupuk NPK $\left(\mathrm{P}_{0}\right)$, pemberian pupuk NPK dengan dosis 14 gram $\left(\mathrm{P}_{1}\right)$, pemberian pupuk NPK dengan dosis 18 gram $\left(\mathrm{P}_{2}\right)$, dan pemberian pupuk NPK dengan dosis 22 gram $\left(\mathrm{P}_{3}\right)$. Perlakuan tersebut hanya dilakukan satu kali selama penelitian dilaksanakan.

Bibit yang digunakan dalam penelitian ini adalah bibit yang berumur 4-5 bulan dan mempunyai tinggi yang relatif seragam. Sebelum pupuk NPK ditabur disekeliling tanaman, tanah digali $1 \mathrm{~cm}$, Selanjutnya pupuk di tabur di sekeliling bibit tanaman kopi dan setelah itu ditutup lagi dengan tanah dan diaplikasikan satu kali selama penelitian.

Pemeliharaan yang dilakukan adalah penyiraman pada pagi atau sore hari tergantung pada kondisi media tanam, penyiangan dilakukan apabila ada gulma tumbuh disekeliling polybag.

Aplikasi perlakuan dilakukan pada bibit yang berumur 4-5 bulan, pengaplikasian pupuk dilakukan satu kali sesuai taraf perlakuan yang telah ditentukan. Pengambilan data hanya lima kali yakni sebelum pengaplikasian pupuk satu kali dan setelah pengaplikasian pupuk NPK empat hari. Data yang diolah adalah data terakhir yang dilakukan setelah 3 bulan pengukuran pertama.

Parameter pengamatan meliputi:

- Tinggi tanaman $(\mathrm{cm})$, yang diukur sebelum dan setelah pengaplikasian pupuk mulai dari pangkal tunas hingga titik tumbuh tanaman dengan menggunakan meteran.

- Jumlah daun (helai), dihitung sebelum dan setelah pengaplikasian pupuk dengan menghitung semua jumlah daun yang ada.

- Diameter batang $(\mathrm{cm})$, Pertambahan diameter batang bawah diukur sebelum dan setelah pengaplikasian pupuk dengan menggunakan jangka sorong, batang bawah diukur $5 \mathrm{~cm}$ dari permukaan tanah 


\section{HASIL DAN PEMBAHASAN}

\section{Tinggi Tanaman}

Hasil analisis sidik ragam menunjukkan bahwa penggunaan pupuk NPK terhadap pertumbuhan bibit kopi memberikan pengaruh tidak nyata terhadap rata-rata tinggi tanaman kopi, namun demikian Gambar 1 memperlihatkan bahwa pemberian pupuk NPK dengan perlakuan dosis 14 gram cenderung memberikan tinggi tanaman yang paling tinggi yaitu 4,33 cm dibandingkan perlakuan lainnya,

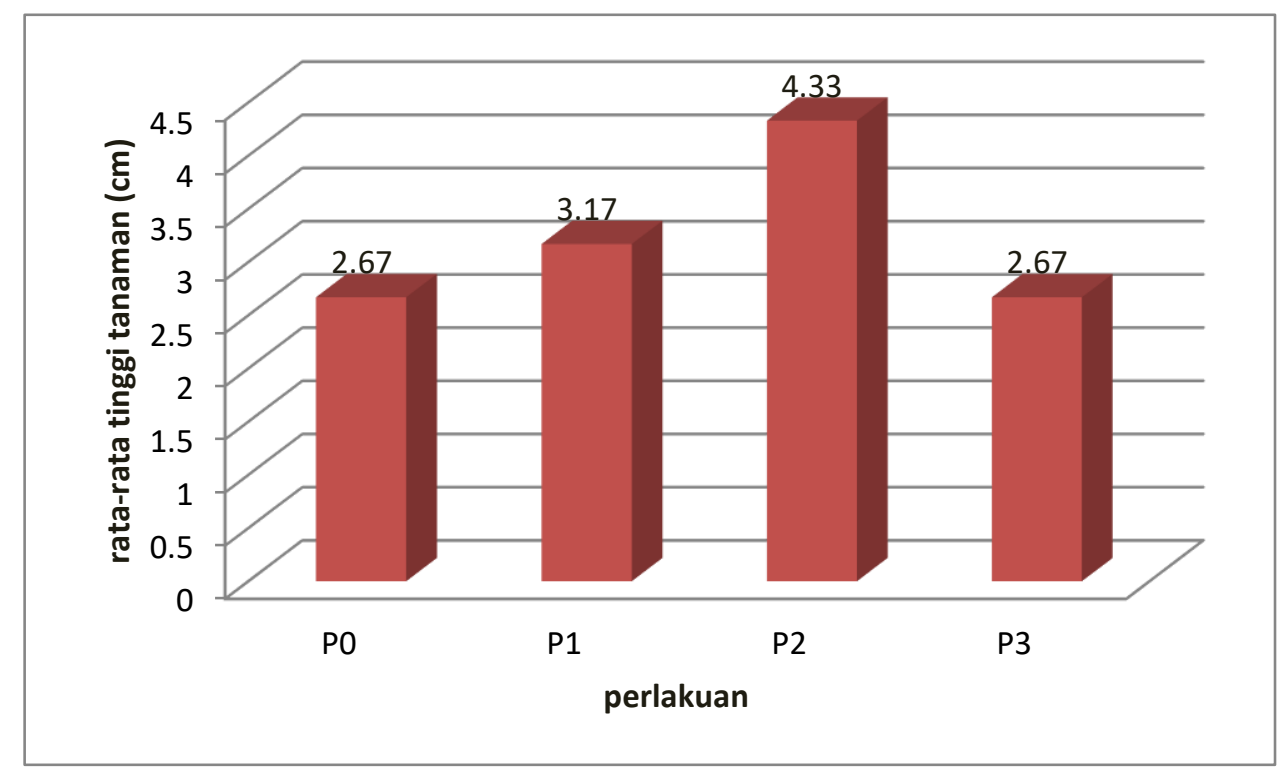

Gambar 1. Rata-rata tinggi tanaman kopi pada pemberian pupuk NPK

\section{Jumlah Daun (Helai)}

Berdasarkan hasil pengamatan dari hasil analisis sidik ragam jumlah daun (helai) tanaman, hasil analisis sidik ragam menunjukkan bahwa penggunaan pupuk NPK terhadap pertumbuhan bibit kopi memberikan pengaruh tidak nyata terhadap rata-rata jumlah helaian daun tanaman kopi, namun demikian pupuk NPK dengan perlakuan dosis 22 gram cenderung memberikan jumlah helai daun tertinggi dibandingkan perlakuan lainnya (Gambar 2).

\section{Diameter Batang}

Hasil analisis sidik ragam menunjukkan bahwa penggunaan pupuk NPK memberikan pengaruh tidak nyata terhadap diameter batang tanaman kopi, namun demikian pupuk NPK dengan dosis 18 gram, 22 gram dan kontrol cenderung memberikan jumlah tertinggi dibandingkan dosis 14 gram (Gambar 3) 


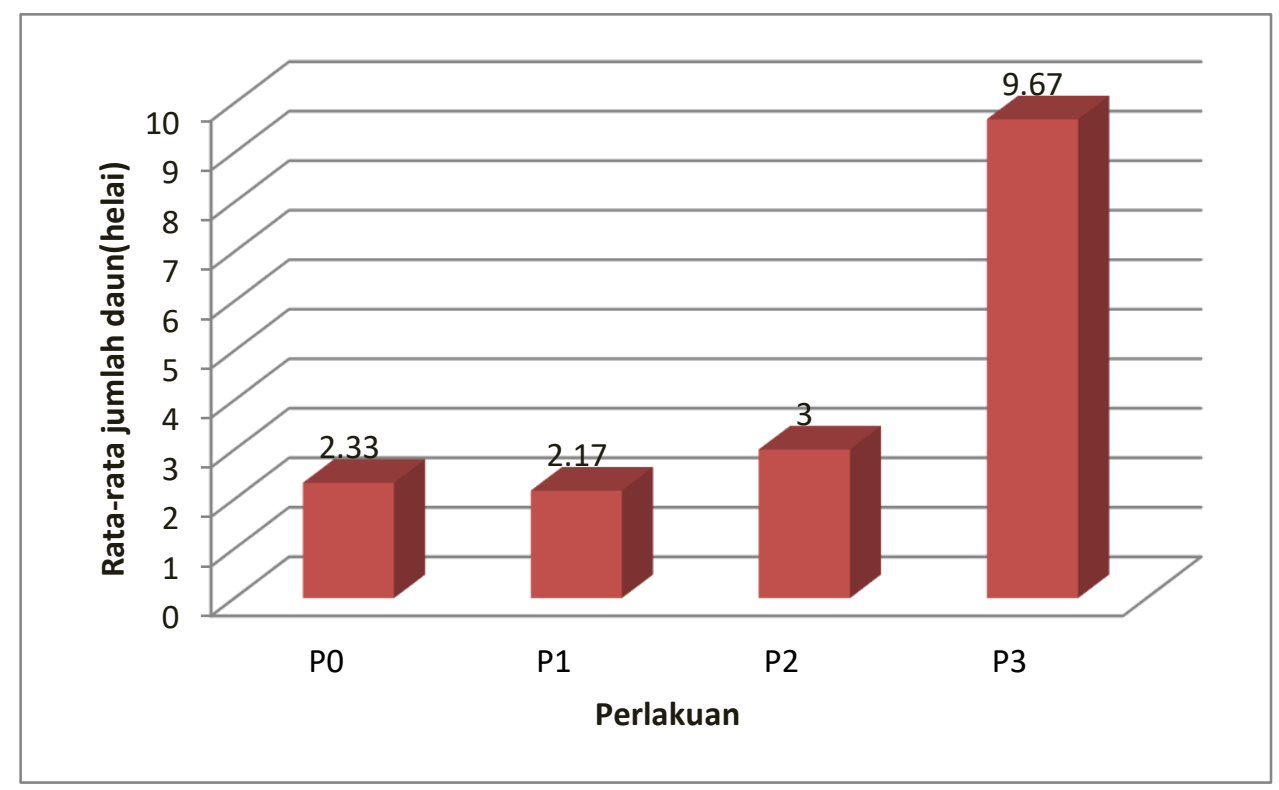

Gambar 2. Rata-rata jumlah daun tanaman kopi pada pemberian pupuk NPK

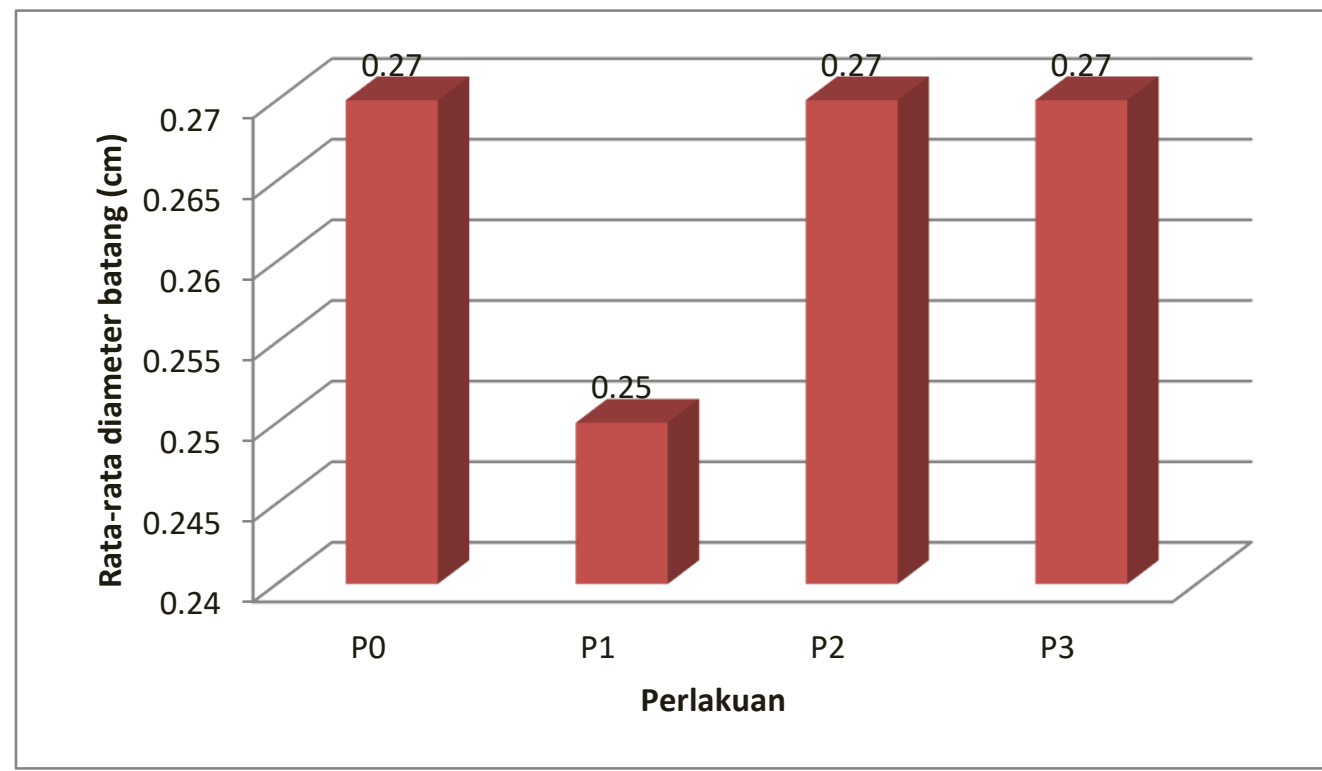

Gambar 3. Rata-rata Diameter batang kopi pada pemberian pupuk NPK

Berdasarkan hasil analisis sidik ragam menunjukkan bahwa pemberian pupuk NPK berpengaruh tidak nyata terhadap pertumbuhan tanaman kopi pada parameter tinggi tanaman, jumlah daun, dan diameter batang. Hal ini diduga disebabkan karena pemberian pupuk tidak berpengaruh, karena cadangan makanan yang tersedia dalam kotiledon masih mencukupi untuk pertumbuhan bibit tanaman kopi, sehingga perbedaan tinggi tanaman yang dihasilkan akibat aplikasi pupuk NPK masih belum berbeda secara nyata, demikian pula pada jumlah daun dan diameter batang bibit tanaman kopi. Hal ini didukung oleh Lakitan (2011) yang menjelaskan bahwa jika jaringan tanaman mengandung unsur hara tertentu, dengan konsentrasi yang lebih tinggi dari konsentrasi yang dibutuhkan untuk pertumbuhan maksimum, maka pada kondisi ini 
dikatakan tanaman dalam kondisi konsumsi mewah (luxury consumption). Pada konsentrasi yang terlalu tinggi unsur hara esensial dapat menyebabkan ketidakseimbangan penyerapan unsur hara lain pada proses metabolisme tanaman.

Secara visual terlihat bahwa perlakuan dengan pemberian dosis pupuk 14 gram pada parameter jumlah daun memberikan hasil lebih tinggi dibandingkan perlakuan lainnya dan pemberian dosis pupuk 18 gram pada parameter tinggi tanaman dan diameter batang memberikan pengaruh yang baik dibandingkan perlakuan lainnya. Hal ini berarti pemberian pupuk dengan dosis 14 gram pada parameter jumlah daun dan pemberian pupuk dengan dosis 18 gram pada parameter diameter batang efektif. Pemberian pupuk tersebut, memenuhi kandungan hara dan dosis tersebut sudah cukup optimal untuk pertumbuhan tanaman. Menurut Harjadi (2009), penetapan pupuk yang tepat dengan dosis yang tepat merupakan faktor penting dalam pemupukan, kemampuan tanaman dalam menyerap hara akan menambah kekuatan tinggi bagi tanaman dan apabila unsur-unsur tersebut bekerja secara optimal maka akan menjadi lebih baik.

Pemberian pupuk dengan dosis pupuk 18 gram pada tinggi tanaman lebih baik dibanding pemberian dosis pupuk 14 gram, hal ini bisa terjadi karena pemberian pupuk dengan dosis pupuk 18 gram sudah memenuhi kandungan hara dan dosis tersebut sudah cukup optimal untuk pertumbuhan tanaman. Menurut Setyamidjaja (2009), menambahkan bahwa efisiensi pemupukan yang sesuai kebutuhan dapat dicapai apabila pupuk diberikan dalam jumlah yang sesuai kebutuhan tanaman, tidak terlalu banyak dan tidak terlalu sedikit. Bila pupuk diberikan banyak maka larutan akan terlalu pekat sehingga mengakibatkan tanaman keracunan.

Fungsi nitrogen merangsang pertumbuhan tanaman secara keseluruhan , merangsang pertumbuhan vegetatif (warna hijau) seperti daun. Fungsi phospat merangsang pertumbuhan akar, merangsang pembelahan sel tanaman dan memperbesar jaringan sel. Fungsi kalium berfungsi pada proses fotosintesa, pengangkutan hasil asimilase, enzim, dan mineral termasuk air. Pupuk NPK berperan penting pada tanaman.

\section{KESIMPULAN}

Berdasarkan hasil dapat disimpulkan bahwa pemberian pupuk NPK berpengaruh tidak nyata terhadap parameter tinggi tanaman, jumlah daun dan diameter batang tanaman kopi.

\section{UCAPAN TERIMA KASIH}

Dismapaikan terima kasih dan penghargaan kepada Direktorat Jenderal Pendidikan Vokasi, Kementerian Pendidikan dan Kebudayaan (Kemendikbud) yang telah mendanai penelitian ini. 


\section{DAFTAR PUSTAKA}

AAK. 1991. Budidaya Tanaman Kopi. Kanisus, Yogyakarta.

Hardjowigeno, S., 2007. Ilmu Tanah. Akademika Pressindo, Jakarta.

Harjadi, S. S., 2009. Zat Pengatur Tumbuhan. Penebar Swadaya, Jakarta.

Hoffman, James. 2014. The World Atlas of Coffee: From Beans to Brewing - Coffees Explored, Explained and Enjoyed. Octopus Publishing Group Limited, London.

Kementerian Pertanian, 2016. Outlook Kopi. Komoditas Pertanian SubSektor Perkebunan. Pusat Data dan Sistem Informasi Pertanian Sekretariat Jenederal Kementerian Pertanian, Jakarta.

Lakitan, B. 2011. Dasar-Dasar Fisiologi Tumbuhan. Rajagrafindo Persada, Jakarta.

Mekuria, T., Neuhoff, D., Kopke, U., 2004. The Status of Coffee Production and The Potential For Organic Conversion in Ethiopia. Conference on International Agricultural Research for Development. Berlin.

Najiyati, S., dan Danarti, 1997. Kopi, Budidaya dan Penanganan Lepas Panen. Penebar Swadaya, Jakarta.

Prastowo, B, E. Karmawati, Rubijo, Siswanto, C. Indrawanto, dan S.J. Munarso, 2010. Budidaya dan Pasca Panen Kopi. Pusat Penelitian dan Pengembangan Perkebunan, Bogor.

Sutedjo, M. M., 2008. Pupuk dan Pemupukan. Penerbit Rineka Cipta, Jakarta.

Setymidjaja, D., 2009 Pupuk dan Pemupukan. CV. Simplex, Jakarta. 